\title{
IMPACTS OF LEACHATE FLOW CONDITIONS ON THE DURATION OF THE AFTERCARE PERIOD
}

\author{
Johann FELLNER \\ Gernot DÖBERL \\ Paul H. BRUNNER \\ Institute of Water Quality and Waste Management \\ Vienna University of Technology, Austria
}

\begin{abstract}
The environmental impacts of deposited MSW are mainly associated with the emissions of leachate and biogas. While biogas emissions will become negligible within decades, leachate emissions will stay on an environmental incompatible level for hundreds of years, calculated under simplified assumptions. The generation of leachate from MSW landfills is determined by the waste input, the climatic conditions and the landfill construction and operation. In this paper the impacts of different construction (landfill cover) and operation strategies (recirculation or flushing) on the duration of landfill aftercare (in particular leachate treatment) are evaluated. Therefore a mathematical water flow and solute transport model which has been successfully calibrated at full scale landfills is used. The results indicate that the stabilization process of MSW landfills is mostly determined by the internal flow conditions and that operation strategies have less impact. Only the warranty of "homogeneous" water flow allows sufficient operation of strategies for accelerated stabilization of MSW landfills.
\end{abstract}

\section{KEYWORDS}

Landfill leachate; Water flow modelling; Salt emissions; Aftercare period; Landfill cover; Flushing.

\section{INTRODUCTION}

The greatest part of the solid waste generated world wide is deposited in landfills without any pre-treatment. The environmental impacts of those landfills are associated mainly with the emissions of leachate and biogas. While biogas emissions will become negligible within decades, leachate emissions will stay on an environmentally incompatible level for hundreds of years. Belevi \& Baccini (1987), Stegmann \& Heyer (1995) and Ehrig \& Krümpelbeck (2001) assessed necessary durations of 200 to 500 
KALMAR ECO-TECH'03

Bioremediation and Leachate Treatment

KALMAR, SWEDEN, November 25-27, 2003

years for the aftercare period. In order to accelerate the stabilization processes in MSW landfills and, thus, shorten the aftercare period, different strategies have been introduced in recent years. All these strategies are mainly based on increased water- and/or air-entry into the landfill.

In the last two decades water and water flow were identified as the main factors determining the metabolism of MSW landfills, as water is on the one hand essential for the biochemical decomposition of the organic substance and on the other hand needed for leaching of soluble compounds. Different investigations (Klink \& Ham, 1982; Bogner \& Spokas, 1993; Christensen et al., 1996) showed that enhanced water flow through waste leads to an acceleration of biochemical processes, as water is the only carrier of substances within a landfill and only water flow facilitates the redistribution of chemicals, micro-organisms and nutrients. Based on these cognitions different concepts have been developed to shorten the aftercare period. They span from unhindered precipitation input (permeable cover layers) over leachate recirculation till forced flushing of pollutants ("Flushing-Bioreactor"). It is assumed that the duration of the aftercare period is more or less inverse proportional to the water flow rate through the landfill.

Beaven \& Walker (1997) determined a required water amount of 6 to $7 \mathrm{~m}^{3} / \mathrm{t}(\mathrm{DS}) \mathrm{MSW}$ to stabilize the waste. Similar results were obtained by Allgaier et al. (2003), who attest old small depositions of MSW negligible hazardous potential, if the liquid-solid ratio is higher than 5 . This equals a water amount of $7.2 \mathrm{~m}^{3} / \mathrm{t}(\mathrm{DS}) \mathrm{MSW}$ under the assumption of an initial water content of MSW of $30 \%$. All these data are derived either from small scale experiments in the laboratory using so-called landfill simulation reactors (LSR) with an experimental volume between 0.1 and $1 \mathrm{~m}^{3}$ of waste or from small landfills with an average height of less than $4 \mathrm{~m}$.

The application of LSR results to full scale landfills, indirectly, implies a similar moisture distribution within full scale landfills and LSR. Due to the big difference in the scale it can be assumed that the waste body of LSR is much more homogenous compared to existing landfills with volumes up to some million $\mathrm{m}^{3}$. Additionally to the heterogeneity of the waste itself, the heterogeneous character of landfills is caused by the compaction procedure resulting in horizontal stratification as well as by construction elements such as gas wells or daily cover layers. Some recent studies (Zeiss \& Major, 1993; Bendz, 1998; Rosqvist \& Destouni 2000, Döberl et al., 2002) proved the existence of a highly nonuniform moisture distribution in landfill bodies resulting in rapid water flow through connected channels and slow movement in the surrounding waste matrix. As the presence of water has a major impact on the metabolism of landfills, the effect of different water flow conditions (heterogeneous and homogeneous) on the success of acceleration strategies need to be investigated.

\section{METHODS}

As no studies enhanced water input on full scale landfills are available so far, an adopted water flow and salt emission model (Fellner et al., 2003) was used to simulate the landfill behaviour. The model is based on the solute transport software HYDRUS_2D (Simunek 
et al., 1996), which was developed for simulating transport processes in the unsaturated soil zone.

The implemented water flow concept is based on a 2-dimensionals 2-domain flow field consisting of a matrix area with low hydraulic conductivity and high storage capacity and a preferential flow paths (channel domain) with high hydraulic conductivity and low (or even no) storage capacity (see Figure la). The implemented approach assumes that the water flow is becoming more heterogeneous towards the landfill bottom. This phenomenon is based on tracer studies in landfill cells of different height that indicate increasing preferential flow with increasing depth. In Table 1 a summary of tracer tests in landfills of different scale is given. The breakthrough time expressed in bed volumes indicates the fraction of the water content taking part at the solute transport processes. It is obvious that the landfill height and the breakthrough "time" are inverse proportional. That means the higher the landfill the less the fraction of the water participating at the transport relatively.

Rosqvist et al. (1997) stated that the variability of the moisture content is increasing with depth, which indicates also increasing preferential flow with depth.

This phenomenon, which has not been considered so far, has been taking into account in the water flow model proposed by Fellner et al. (2003).

Table 1 Tracer Experiments in landfills

Tracer test

Rosqvist et al. (2001)

Rosqvist et al. (2001)

Baumann \& Schneider (1998)

Döberl et al. (2002)
Waste volume Waste height $\left[\mathrm{m}^{3}\right]$

[m]

0,14

$\sim 3,5$

$\sim 50000$

$\sim 30000$
0,65

1,2

6

12
Breakthrough „time“ [bed volume]

$\sim 0,68-0,87$

$\sim 0,05-0,1$

$\sim 0,006$

$\sim 0,0008$ 
A)

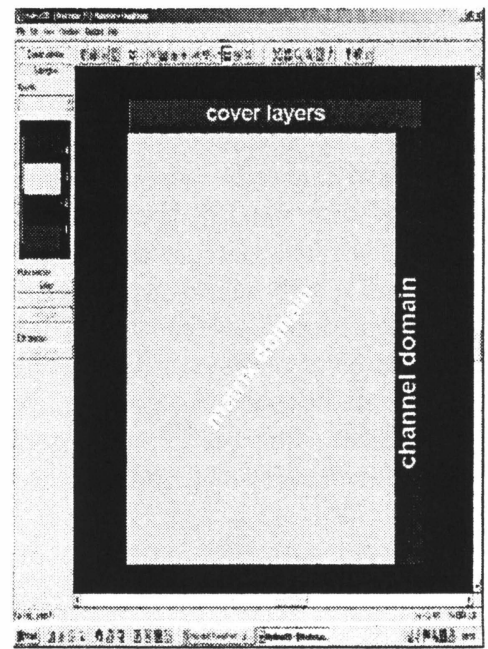

B)

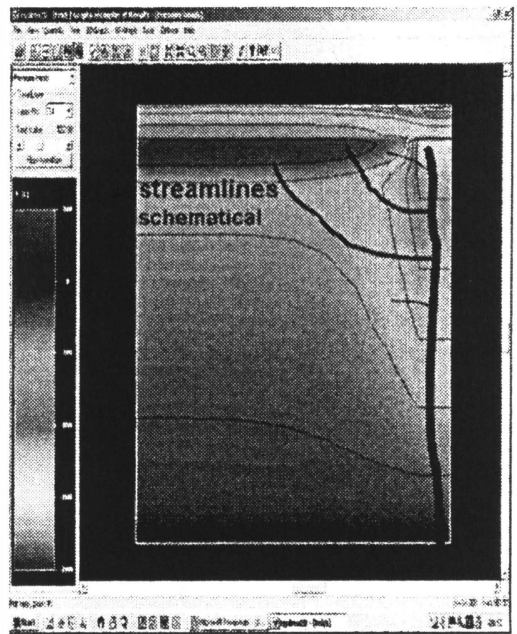

Figure 1 2-dimensional 2-domain concept (1A) and resulting flow field (1B) (Fellner et al., 2003)

The resulting pressure head distribution (shown in Figure $1 \mathrm{~b}$ ) confirms that the implemented 2-dimensional 2-domain concept corresponds to the flow pattern in landfills.

The calibration and verification of the adopted model was carried out using data from a trial landfill (Breitenau, Riehl-Herwirsch et al. 1995) in Austria. This landfill has been operated since 1987 containing 95,000 tons of MSW. The landfill surface covers an area of $1.1 \mathrm{ha}$. The average landfill depth is around $12 \mathrm{~m}$.

Using the 2-dimensional 2-domain approach it was possible to simulate both, the base flow as well as the peaks corresponding to precipitation events. Figure 2 shows the calculated and the observed leachate discharge of compartment 1 of the landfill Breitenau.

Based on the water flow simulations the discharge of soluble compounds (sodium) was modelled assuming that the whole amount of sodium (around 1,400 mg Na/kg DS MSW) is already dissolved in the immobile water phase at the beginning of the simulation. This assumption confines that the transport processes to be modelled were restricted to the diffusion process from the immobile water phase into the mobile water phase and the convective transport within the mobile water phase. Due to the low temporal resolution of the measured sodium concentration in the leachate the whole data set had to be used for calibration purposes. The verification of the solute emission model was carried out using information on the total sodium discharge during the whole deposition period. The result of the sodium flow simulation is shown in Figure 3 . There are differences of the modelled 
KALMAR ECO-TECH'03

Bioremediation and Leachate Treatment

KALMAR, SWEDEN, November 25-27, 2003

and the measured graph, especially during the first years of the landfilling process. During this period it can be assumed that the water flow regime was not stable due the larger settlements occurring in this time. However, during the period from June 2001 till June 2002, a quite good agreement between modelled and observed sodium concentrations was achieved.

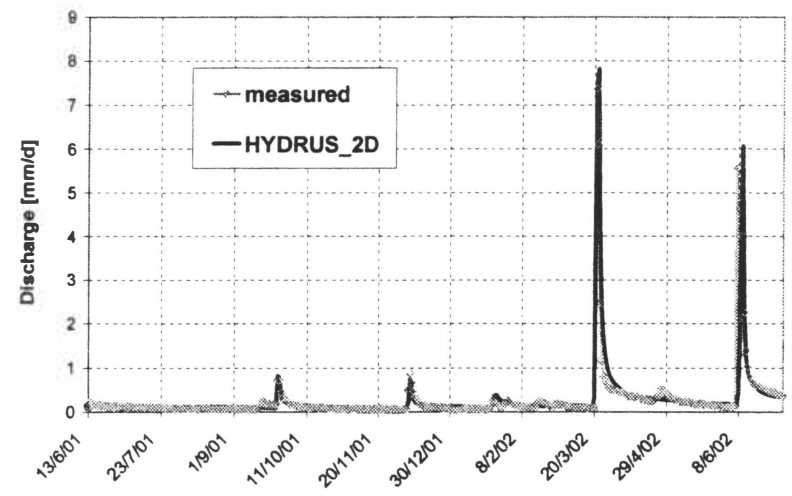

Figure $2 \quad$ Leachate discharge of compartment 1 (observed and simulated)
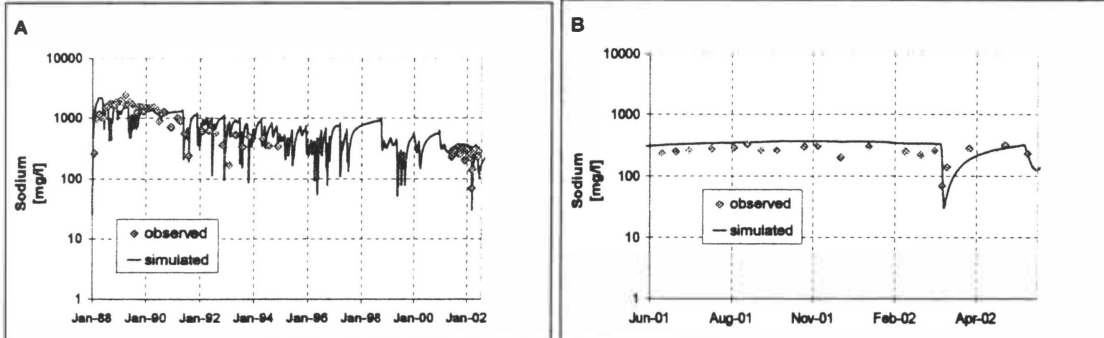

Figure $3 \quad$ Sodium concentration in the leachate of compartment 1 (measured and simulated) A: 1988 (beginning of landfilling - June 2002); B: detail (June 2001-June 2002)

Based on the calibrated and validated transport model, the impacts of different operation strategies on the aftercare period were investigated. The trial landfill Breitenau itself served as study object. The following operation strategies were simulated and compared: 
KALMAR ECO-TECH'03

Bioremediation and Leachate Treatment

KALMAR, SWEDEN, November 25-27, 2003

- strategy 1A: current status, actual landfill cover: $90 \mathrm{~cm}$ silty sand, net water application rate: $0.5 \mathrm{~mm} / \mathrm{d}$

- strategy 2A: open landfill: no cover layer net water application rate: $1.0 \mathrm{~mm} / \mathrm{d}$

- strategy 3A: flushing bioreactor: forced water injection at the surface water application rate $10 \mathrm{~mm} / \mathrm{d}$

Additionally all three cases were calculated assuming ideal homogenous flow conditions. Therefore the denotation of the strategies is changed from A to B (for instance "strategy $1 \mathrm{~A}$ " -heterogeneous flow with $0.5 \mathrm{~mm} / \mathrm{d}$ becomes "strategy 1B" - homogeneous flow with $0.5 \mathrm{~mm} / \mathrm{d}$ ).

In this study the "virtual" end of the aftercare period is reached, after the leachate concentrations dropped to a value of $1 / 100$ of the initial pollutant concentrations. This postulation is based on investigations of Knox (2001), who stated that the initial concentration of leachate pollutants exceeds legal limit values for direct discharge about a factor of 40 to 200. Therefore an average dilution of the initial concentrations of around 100 is required to meet the legal limit values. To refer all the calculations to the same concentration value the virtual limit leachate concentration is set to $1 / 100$ of the initial concentration of the current status of the landfill (strategy 1A).

\section{RESULTS}

\subsection{Actual (heterogeneous) flow conditions}

According to the considered operation strategies water flow rates varying from $0.5 \mathrm{~mm} / \mathrm{d}$ up to $10 \mathrm{~mm} / \mathrm{d}$ were simulated using the calibrated water flow and solute transport model. In Figure 4 the results of the simulations for heterogeneous flow conditions are summarized. The diagram is standardised. The concentration values and the time scale are referred to the results of strategy $1 \mathrm{~A}$. That means for strategy $1 \mathrm{~A}$ the initial concentration is 1 and also the time period till a dilution of 100 (concentration equals 0.01 ) is reached is 1 .

Doubling the water flow (strategy $2 \mathrm{~A}$ ) leads to a shortening of the aftercare period of around $40 \%$. An increase of the water flow of about 20 times (strategy $3 \mathrm{~A}$ ) causes a reduction of the aftercare period of around $90 \%$. These results indicate that enhanced water flow through landfills requires more water to reach a certain concentration limit value, as the aftercare period are not shortened by the same factor than the water flow is increased. 


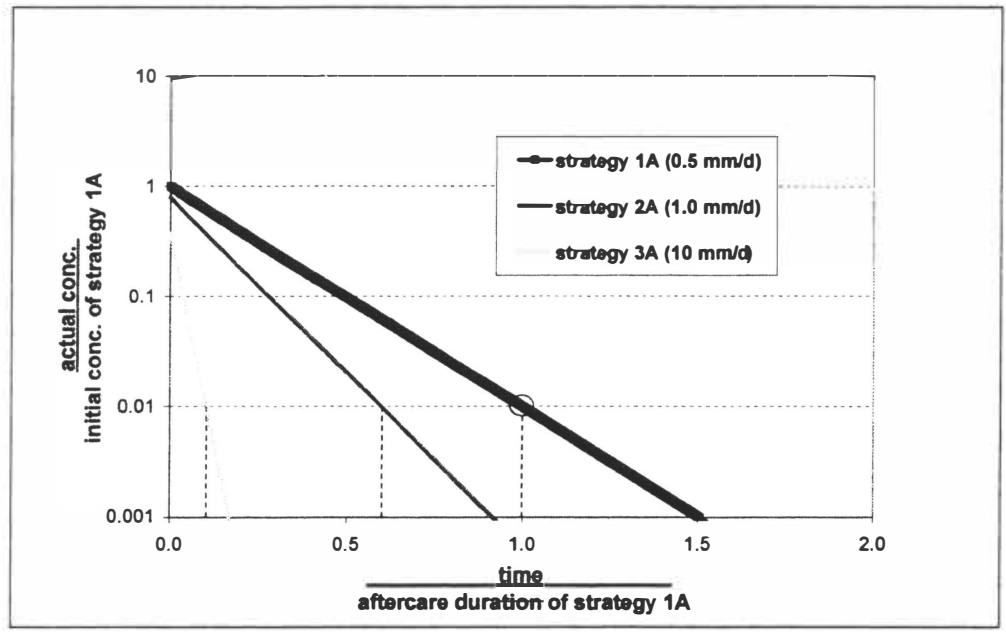

Figure 4 Leachate concentrations for heterogeneous flow conditions (standardised diagram)

\subsection{Ideal (homogenous) flow conditions}

The same simulations for the salt concentration in the leachate were carried out assuming ideal homogeneous flow conditions in the landfill. Also here the water flow rate was varied from $0.5 \mathrm{~mm} / \mathrm{d}$ to $10 \mathrm{~mm} / \mathrm{d}$. The results were referred to the current status strategy 1A (see Figure 5). Homogeneous flow conditions have two impacts on the time dependent leachate characteristics. Initial concentrations are raised and also the decrease of concentration values per time unit is less compared to the results for heterogeneous flow conditions. Both phenomena cause longer aftercare periods. Compared to strategy $1 \mathrm{~A}$ an increase of nearly $80 \%$ is noted for homogeneous flow till the concentrations drop the limit value. 


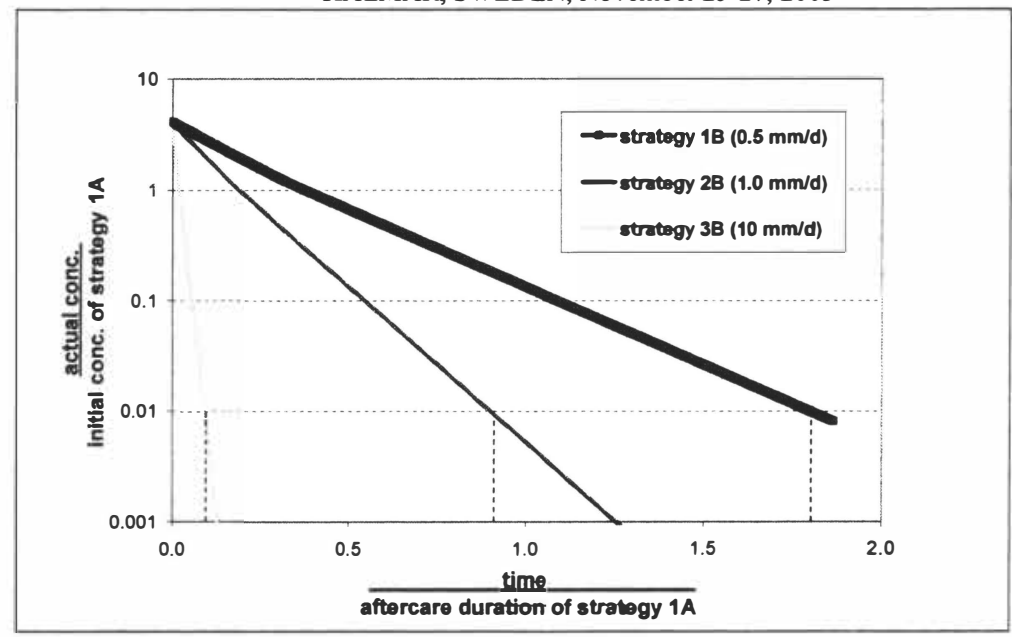

Figure $5 \quad$ Leachate concentrations for homogenous flow conditions (standardised diagram)

In case that the end of the aftercare period is defined only by the actual emission level (actual leachate concentration values), a more heterogeneous flow field seems to be desirable due to the fact that lower concentration values are reached earlier. However, taking not only the actual emission level into account, but also the future (remaining) emission potential, leads to a completely different result.

Figure 6 shows the discharged fraction of pollutants for ideal homogenous and current heterogeneous flow conditions. For homogenous water flow nearly all the salt $(>99 \%)$ has been discharged at the end of the "virtual" aftercare period, whereas for heterogeneous flow conditions more than $80 \%$ of the initial pollutant load is still remaining inside the landfill body and represents a high emission potential for the future. Changes of the flow paths could lead to sudden increase in the leachate concentration.

That implicates actual low concentration values which are "compatible" with the environment, are no reliable indicators for ending the aftercare period. The remaining emission potential must be taken into account to evaluate the stabilization status of a landfill. 


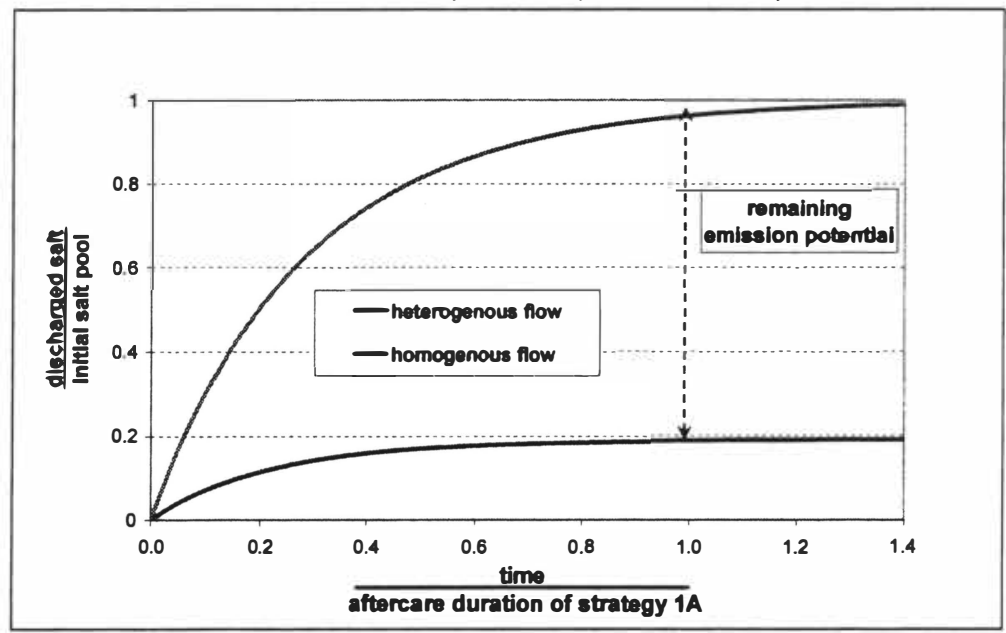

Figure 6 Comparison of homogenous and heterogeneous flow condition (standardised diagram)

\section{SUMMARY AND CONCLUSIONS}

As water plays an important role in the metabolism of landfills, increased water input into the landfill is believed to shorten the aftercare period. The effect of different water application rates on the aftercare was investigated using the water and solute transport model HYDRUS 2D. Under the assumption of a 2-dimensional 2-domain flow field, it was possible to simulate the leachate flow of a landfill at field scale. Raised water input into the waste body leads to accelerated decrease of salt concentrations in the leachate. Thus, legal limit values for the leachate concentration can be reached earlier. However, achieving low concentration values is no indicator for ending the aftercare period, as due to the heterogeneous water flow conditions within landfills, a high emission potential is still remaining (see Figure 6). A comparison of current heterogeneous flow conditions with ideal homogeneous flow conditions indicate that the success of accelerated stabilization strategies depends on the degree of heterogeneity of water flow.

Current strategies (e.g. flushing) for shortening the aftercare period are expedient only under the condition of a more or less evenly moisture distribution within landfills.

\section{ACKNOWLEDGEMENTS}

The authors gratefully acknowledge the financial support of the Austrian Federal Ministry of Agriculture, Forestry, Environment and Water Management. The funding was administrated by the Kommunalkredit Austria AG. 


\section{REFERENCES}

[1] Allgaier, G., 2003. Development of a New Risk Assessment Model for Small Old Landfills. In: T.H. Christensen, Cossu, R. \& Stegmann, R. (Editor), Proceedings Sardinia 2003, Ninth International Waste Management and Landfill Symposium. CISA, S. Margherita di Pula.

[2] Baumann, T. and Schneider, M., 1998. Dynamik des Wasserhaushaltes von Hausmülldeponien. EntsorgungsPraxis(3/98)a45-49.

[3] Beaven, R.P. and Walker, A.N., 1997. Evaluation of the total potential load of MSW. In: T.H. Christensen, Cossu, R. \& Stegmann, R. (Editor), Proceedings Sardinia 97, Sixth International Waste Management and Landfill Symposium. CISA, S. Margherita di Pula, pp. 57-71.

[4] Belevi, H. and Baccini, P., 1989. Long-Term Behaviour of Municipal Solid Waste Landfills. Waste Management \& Research, 7: 43-56.

[5] Bendz, D., 1998. Generation of leachate and the flow regime in landfills. AFRreport 191, Lund, 27 s. pp.

[6] Bogner, J. and Spokas, K., 1993. Landfill CH4: Rates, fates, and role in global carbon cycle. Chemosphere, 26(1-4): 369-386.

DOI: https://doi.org/10.1016/0045-6535(93]90432-5

[7] Christensen, T.H., Kjeldsen, P. and Lindhardt, B., 1996. Gas-generating processes in landfills. In: R.C.a.R.S. T.H. Christensen (Editor), Landfilling of waste: biogas. E\&FN Spon, London.

[8] Döberl, G., Huber, R., Fellner, J. and Brunner, P.H., 2003. The Heterogeinity of Waste as a Main Factor Influencing the Future Emission Potential of MSW Landfills - A Case Study on the Breitenau-Landfill in Austria. In: T.H. Christensen, Cossu, R. \& Stegmann, R. (Editor), Proceedings Sardinia 2003, Ninth International Waste Management and Landfill Symposium. CISA, S. Margherita di Pula.

[9] Döberl, G., Huber, R., Fellner, J., Cencic, O. and Brunner, P.H., 2002. Neue Strategien zur Nachsorge von Deponien und zur Sanierung von Altlasten (Projekt STRANDEZA), Abteilung Abfallwirtschaft und Stoffhaushalt, Technische Universität Wien.

[10] Ehrig, H.J. and Krümpelbeck, I., 2001. The Emission Behaviour of Old Landfills in the Aftercare Phase. In: T.H. Christensen, Cossu, R. \& Stegmann, R. (Editor), Proceedings Sardinia 2001, Eigth International Waste Management and Landfill Symposium. CISA, S. Margherita di Pula, pp. 313-323.

[11] Fellner, J., Huber, R., Döberl, G. and Brunner, P.H., 2003. Hydraulics of MSW landfills and its implications for water flow modelling. In: T.H. Christensen, 
KALMAR ECO-TECH'03

Bioremediation and Leachate Treatment

KALMAR, SWEDEN, November 25-27, 2003

Cossu, R. \& Stegmann, R. (Editor), Proceedings Sardinia 2003, Ninth International Waste Management and Landfill Symposium. CISA, S. Margherita di Pula.

[12] Klink, R.E. and Ham, R.K., 1982. Effects of moisture movement on methane production in solid waste landfill samples. Resources and Conservation, 8(1): 2941. doi: https://doi.org/10.1016/0166-3097(82)90051-7

[13] Knox, K., 2001. New strategies needed? The pros and cons of landfill covering, Weiterbildungsseminar Deponietechnik. Institut für Wassergüte und Abfallwirtschaft, Technische Universität Wien, Wien.

[14] Riehl-Herwirsch, G. et al., 1995. Hausmüllversuchsanlage Breitenau Untersuchungen zum quantitativen und qualitativen Wasserhaushalt 1986-1991, Bundesministerium für Land- und Forstwirtschaft, Vienna.

[15] Rosqvist, H., Bendz, D., Öman, C. and Meijer, J.-E., 1997. Water Flow in a Pilot Scale Landfill. In: T.H. Christensen, Cossu, R. \& Stegmann, R. (Editor), Proceedings Sardinia 1997, Sixth International Waste Management and Landfill Symposium. CISA, S. Margherita di Pula.

[16] Rosqvist, H. and Destouni, G., 2000. Solute transport through preferential pathways in municipal solid waste. Journal of Contaminant Hydrology, 46(1-2): 39-60. doi: https://doi.org/10.1016/S0169-7722(00)00127-3

[17] Rosqvist, H., Röhrs, L. and Fourie, A., 2001. Water Balance and Solute Transport Studies in Three Experimental Solid Waste Columns. In: T.H. Christensen, Cossu, R. \& Stegmann, R. (Editor), Proceedings Sardinia 2001, Eighth International Waste Management and Landfill Symposium. CISA, S. Margherita di Pula, pp. 655-664.

[18] Šimunek, J., Šejna, M. and van Genuchten, M.T., 1996. The HYDRUS_2D Software Package for Simulating Water Flow and Solute Transport in TwoDimensional Variably Saturated Media. Version 1.0., U.S. Department of Agriculture Riverside, California.

[19] Stegmann, R., 1995. Langfristiges Gefährdungspotential und Deponieverhalten von Ablagerungen, Statusseminar Deponiekörper. BMBF, Wuppertal.

[20] Zeiss, C. and Major, W., 1993. Moisture Flow through Municipal Solid Waste: Pattern and Characteristics. Journal of Environmental Systems, 22(3)a211-232. 